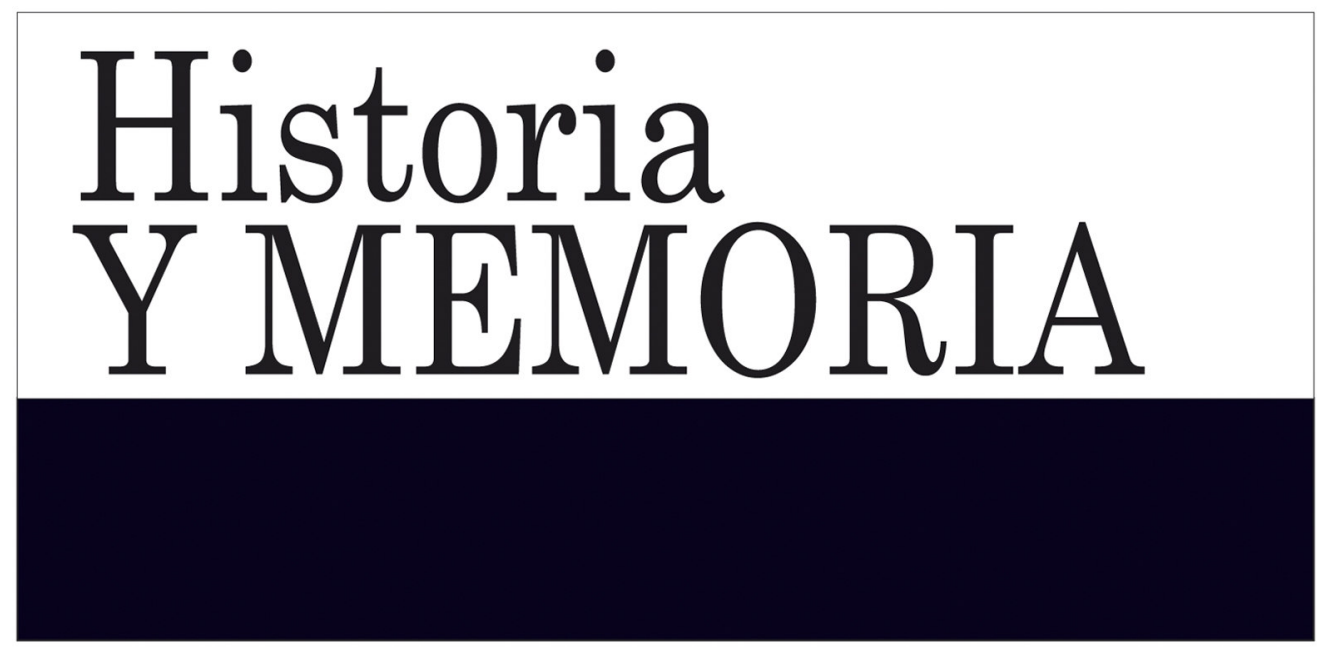

ISSN: 2027-5137 Julio - Diciembre, Año 2014 - Tunja, Colombia

Guerrilla y población civil. La trayectoria de las FARC, 1949-2013. Informe del Centro Nacional de Memoria Histórica William Mancera Páginas: 315 - 318

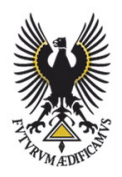




\title{
Mario Aguilera Peña, Guerrilla y Población Civil. La trayectoria de las FARC, 1949-2013. Informe del Centro Nacional de Memoria Histórica (Bogotá, Imprenta Nacional, 2013).
}

\author{
William Mancera \\ Historiador, Universidad Nacional. \\ Investigador del Centro Nacional de Memoria Histórica. \\ Bogotá-Colombia.
}

\section{Desentrañando a las FARC}

Recientemente el Centro Nacional de Memoria Histórica $(\mathrm{CNMH})$ lanzó el informe escrito por Mario Aguilera, investigador del Instituto de Estudios Políticos y Relaciones Internacionales (IEPRI). El informe ofrece una síntesis de la evolución de las FARC desde sus orígenes como autodefensas comunistas en 1949 hasta la actualidad. Esta recapitulación pone en juego tres variables fundamentales: las representaciones que la guerrilla tiene de sí misma y las que elabora la sociedad sobre ese actor armado; la evolución militar en un sentido amplio (estrategias, métodos de guerra, recursos y dominios territoriales); igualmente, muestra la dinámica de las relaciones, intercambios e impactos de la guerrilla frente a la población civil.

\section{Las FARC: ¿de víctimas a victimarios?}

El informe permite identificar en las diversas fases de existencia de las FARC el universo de sus representaciones e imaginarios. Se muestra que una de las fortalezas de la guerrilla, por lo menos interna, es que ha cultivado una memoria histórica que destaca las agresiones o violencias de las que ha sido 
víctima. Esto con el objeto de darle una legitimidad a su lucha, aduciendo que ha hecho uso de una violencia de respuesta frente a la violencia injustificada del Estado. En su memoria colectiva tienen como lugares destacados la persecución contra las autodefensas agrarias, la agresión contra Marquetalia, el aniquilamiento de la Unión Patriótica, el bombardeo contra Casa Verde, las acciones paramilitares apoyadas por agentes del Estado, el Plan Colombia, etc. A ese imaginario, se suma el patriótico, a partir de los años noventa, que toma como eje la lucha de Simón Bolívar. Esta fuerte referencia patriótica en el simbolismo guerrillero buscaba coincidencias y continuidades entre las luchas por la liberación política y social en el siglo XIX, con los postulados políticos de la insurgencia.

La idea de unas FARC como víctimas del Estado se fue desdibujando paulatinamente. A ello contribuyeron los cambios culturales que deslegitimaron el uso de la violencia como instrumento para el cambio social; el uso de recursos provenientes del narcotráfico y algunos de sus métodos de guerra (secuestro, minas antipersonal, destrucción de infraestructura pública, etc.,). Igualmente, porque las FARC se convertirían desde mediados de los noventa en un ejército intimidante, bien armado y ofensivo que pugnaba cada vez más por cercar las capitales del departamento. Fue entonces, según el informe, que las FARC dejaron de ser consideradas como portadoras de una violencia de respuesta para convertirse en ejecutoras de una violencia agresiva y "sobre todo sin excusa". Ese pensamiento inscrito en una parte importante de la opinión colombiana llevaría a justificar la acción represiva contra dicha guerrilla e incluso a aceptar por lo menos pasivamente la acción del paramilitarismo.

\section{Profundamente coherentes en la guerra}

Otro aspecto destacado del libro es el seguimiento a la evolución militar de las FARC. Se plantea que esa guerrilla a diferencia de otras, tuvo muy claro su modelo estratégico de guerra e hizo todo lo posible por cumplir sus fases. En líneas generales, se trató de un plan militar de 8 años, que por sus retrasos y suspensiones terminó prolongándose por más de veinte. 
Consistía, según las fuentes del informe, en el incremento de la fuerza de esa guerrilla a más de 60 frentes con entre 300 y 500 guerrilleros. De estos frentes un $50 \%$, se colocaría en la cordillera oriental rumbo hacia la capital para bloquearla y librar combates en sus alrededores. El otro 50\% debía situarse en el resto del país, dispersando al ejército y paralizando las carreteras nacionales y municipales. En una primera ofensiva se pretendía tomar el control de los departamentos del Caquetá y el Putumayo, mediante la derrota de los batallones de la fuerza pública y la destrucción de los aviones y las pistas de los aeropuertos de esos dos departamentos. A la par, tropas del Bloque Oriental avanzarían sobre la capital y las milicias bolivarianas debían promover la insurrección y la huelga general en las ciudades principales del país.

El texto se ocupa de analizar los diversos factores que impidieron el éxito militar de las FARC entre los que se destacan la ayuda militar norteamericana por intermedio del Plan Colombia, la reorganización y la retoma de la ofensiva de la fuerza pública, la falta de apoyo y la retoma de la ofensiva militar por parte del ejército particularmente durante el gobierno de Uribe Vélez. Después de ello y hasta la actualidad, las FARC pasaron a librar una guerra de resistencia, con un plan estratégico desarticulado y sin una real perspectiva de triunfo.

\section{Expresión de un conflicto político y social}

En otro de sus grandes ejes analíticos el texto recorre los orígenes de esa organización en las guerrillas comunistas de los años cincuenta, mostrando que se trata de una organización que se origina en un conflicto agrario no resuelto y que tiene sus orígenes en las primeras décadas del siglo pasado. Siguiendo la ruta que reconstruye las raíces económicas y sociales de la confrontación, el informe demuestra que esa organización creció y se expandió en zonas colonizadas en la segunda mitad de siglo, sacándole provecho al marginamiento geográfico, el abandono estatal y la pobreza rural. El conflicto se intensificaría hacia los años setenta debido a la difusión de los cultivos de coca, que permitió que en la VII 
conferencia las FARC oficializaran el cobro de un impuesto a los comerciantes y no a los productores como lo estaban haciendo espontáneamente los comandantes en estas zonas. En esas regiones como en otras sin dichos cultivos, las FARC sustituirían algunas de las funciones del Estado, amparando ocupaciones de tierra, contribuyendo a la instauración de organizaciones campesinas, interviniendo en la solución de problemas colectivos (construcción y sostenimiento de caminos, imponiendo impuestos para pagar maestros, etc.) o resolviendo conflictos entre vecinos y generando orden y seguridad en zonas geográficas marginales. Su oferta de seguridad fue particularmente notable en regiones con cultivos de coca en donde se encargaron de regular la producción, respaldar la existencia de cultivos y frenar los atropellos de las bandas de narcotraficantes. A cambio exigieron diversas formas de tributación según las facilidades del "mercado" y la presión de la fuerza pública o de los grupos paramilitares. Por todos los servicios ofrecidos, en unas y otras zonas, la guerrilla exigió lealtad y el cumplimiento a las normas escritas u orales que controlaban el comportamiento de los habitantes de las veredas campesinas. Su incumplimiento podía llevar hasta la pena de muerte. 